\title{
Electrodeposition of titanium-vanadium alloys from chloride-based molten salts: influence of electrolyte chemistry and deposition potential on composition, morphology and microstructure
}

\author{
Joachim Gussone ${ }^{1}$ (D) Chakradhar Reddy Yerragudi Vijay ${ }^{1} \cdot$ Philipp Watermeyer $^{3} \cdot$ Ksenija Milicevic $^{2}$. \\ Bernd Friedrich $^{2} \cdot$ Jan Haubrich ${ }^{1}$
}

Received: 9 July 2019 / Accepted: 16 December 2019 / Published online: 21 January 2020

(c) The Author(s) 2020

\begin{abstract}
In the present study, we demonstrate co-deposition of titanium and vanadium from a eutectic $\mathrm{LiCl}-\mathrm{KCl}$ electrolyte enriched with $\mathrm{VCl}_{3}$ and $\mathrm{TiCl}_{2}$ at $700 \mathrm{~K}$. While the addition of metallic titanium to the electrolyte caused vanadium depletion by a displacement reaction, metallic vanadium addition created and stabilized divalent vanadium ions in the melt, which are supposed to positively affect the deposition process. Various electrochemical experiments were carried out with different electrolyte concentrations, and a relationship between applied potential, electrolyte concentration and composition of the deposit was established. The composition and the morphology of the obtained deposits were strongly affected by the electrolysis conditions. Electrodeposited vanadium-rich Ti-V alloys were found to grow as dendrites, whereas the titanium-rich alloys exhibited a dense cauliflower-like surface morphology. In contrast to deposits of the single elements, which are composed of comparably large faceted crystals, the Ti-V alloys obtained in this study were very fine grained, especially those with vanadium contents around 10-15 at\%. Transmission electron microscopy revealed that, depending on the composition of the deposit, either a biphasic $\alpha+\beta$ microstructure in the case of low vanadium contents or $\beta-(\mathrm{V}, \mathrm{Ti})$ with small amounts of $\omega$ phase for high vanadium contents were found.
\end{abstract}

\section{Graphic abstract}
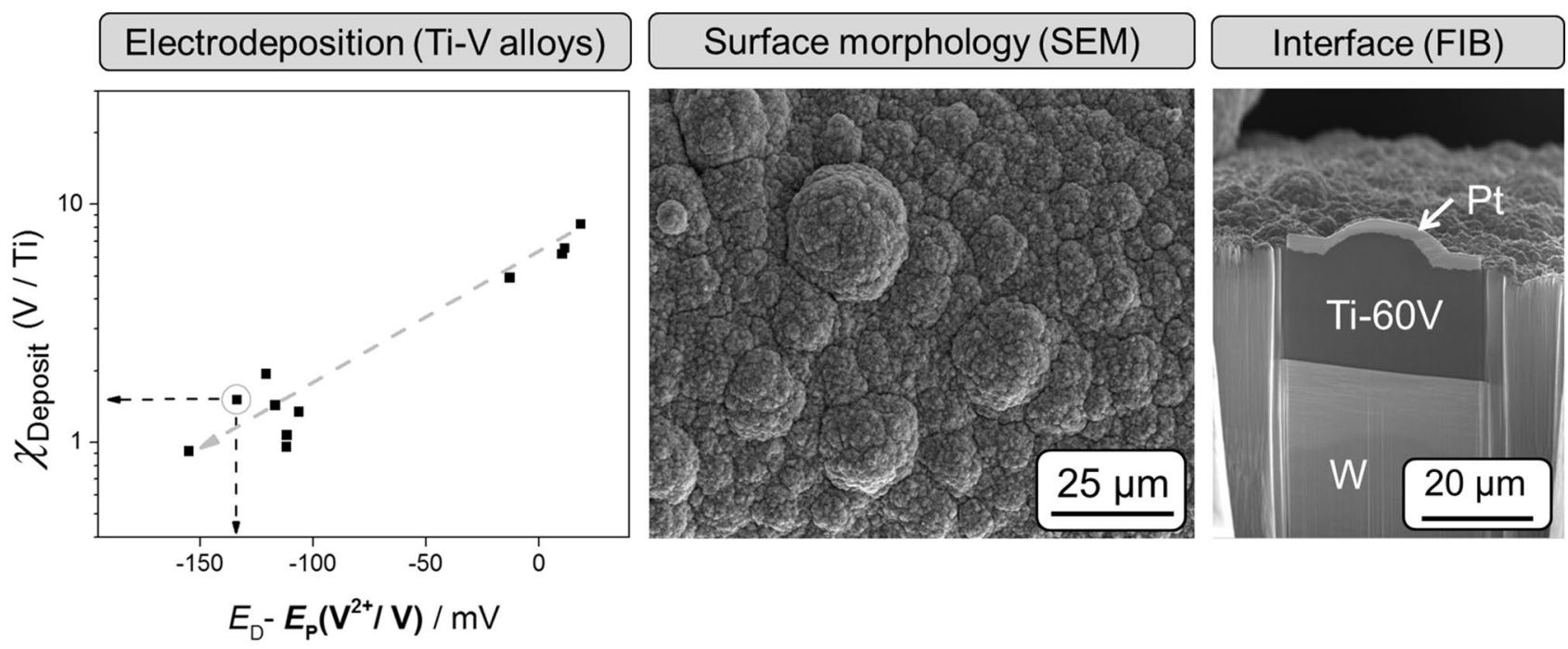

Keywords Electrodeposition $\cdot$ Molten salt $\cdot$ Titanium-vanadium alloys $\cdot \mathrm{LiCl}-\mathrm{KCl}$ eutectic $\cdot$ Anodic dissolution $\cdot$ Element partitioning

Extended author information available on the last page of the article 


\section{Introduction}

Electrochemical syntheses involving electrodeposition can proceed by means of three processes, namely simultaneous deposition of independent ions, reaction and interdiffusion between substrate and coating [1], as well as the reduction of heteronuclear complex ions as, e.g., in the case of $\mathrm{Ti}-\mathrm{Al}$ alloy deposition [2].

Although electrodeposition of alloys from molten salts is rarely investigated, there are a couple of recent publications dealing with Al alloys [3-6], e.g., Al-Cu [3] or $\mathrm{Al}-\mathrm{Ta}$ [6]. The deposition of Ti-Al alloys from chloroaluminates has been extensively studied by Stafford et al. [2, 7-11] including the microstructural characterization of the deposits [8]. Recently, the influence of fluoride ions has been studied in $\mathrm{AlCl}_{3}-\mathrm{NaCl}$ [12]. However, in chloroaluminate electrolytes only comparatively low titanium contents up to 25 at $\%$ could be realized.

Titanium alloy deposition from high-temperature molten salts was described, e.g., in two studies dealing with the co-deposition of $\mathrm{Ti}-\mathrm{Nb}$ [13] and $\mathrm{Ti}-\mathrm{Zr}$ [14] but, to our best knowledge, no literature is available on the deposition of Ti-V alloys. However, an alternative approach should be mentioned, namely the vanadium-titanium alloy powder production from oxides by electroreduction [15].

The electrochemistry of titanium ions [16-18] as well as the electrodeposition of titanium [19, 20] is widely investigated, whereas there are only few articles about electrorefining [21-24] and the electrochemical behaviour of vanadium ions [25] in molten salts.

As recently demonstrated, coherent high-quality vanadium coatings can be deposited from $\mathrm{LiCl}-\mathrm{KCl}$ containing divalent vanadium ions [26]. The present study builds on the latter investigations and forms the next step towards the development of an electrodeposition process for $\mathrm{Ti}-\mathrm{Al}-\mathrm{V}$ alloys, in particular the most important and widely established titanium alloy Ti-6Al-4V [27]. Of secondary, such a process would provide an alternative for synthesis of titanium matrix composites [28]. To this end, the current investigation focuses on identifying suitable electrodeposition parameters for a controlled deposition of titanium and vanadium from $\mathrm{LiCl}-\mathrm{KCl}-\mathrm{VCl}_{3}-\mathrm{TiCl}_{2}$ melts and the characterization of the obtained materials.

\section{Experimental}

\subsection{Chemicals and materials}

All experiments were carried out in a glove box system with a tube furnace under high-purity Argon $\left(\mathrm{H}_{2} \mathrm{O}\right.$,
$\mathrm{O}_{2}<1 \mathrm{ppm}$ ) as described previously [29]. The electrolysis was carried out in glassy carbon crucibles (GCC, HTW, Sigradur G, GAT2). The base electrolyte consisting of a eutectic mixture of $\mathrm{LiCl}$ (Alfa Aesar, ultra dry, 99.9\%) and $\mathrm{KCl}$ (Alfa Aesar, ultra dry, 99.95\%) was enriched with $\mathrm{TiCl}_{2}$ (Sigma-Aldrich, 99.98\% anhydrous) and $\mathrm{VCl}_{3}$ (Alfa Aesar, 99.0\%). Metallic titanium (Alfa Aesar, 99.8\%) or vanadium (Alfa Aesar, 99.5\%) was added to the $\mathrm{LiCl}-\mathrm{KCl}-\mathrm{VCl}_{3}-\mathrm{TiCl}_{2}$ electrolyte in most experiments to generate and stabilize the divalent valence state of the vanadium ions by comproportionation [26]. An overview of the investigated systems is given in Table 1. Please note that the species and concentrations correspond to the added chemicals, i.e., they do not represent the condition during electrolysis which changes because of reactions described in Sect. 3.1. The values in Table 1 will be maintained in the article for the sake of clarity.

All experiments were carried out with tungsten wires $(\varnothing$ $0.14 \mathrm{~mm}$, Alfa Aesar, 99.95\%) as working electrodes (WE) and also tungsten wires ( $\varnothing 0.5 \mathrm{~mm}$, Alfa Aesar, 99.95\%) as counter electrodes (CE). The glassy carbon crucible served additionally as quasi reference electrode (QRE). For experiments, in which metallic vanadium was added to the electrolyte and had contact to the GCC, the reference electrode is designated V, GC-QRE.

\subsection{Experimental procedure}

The electrochemical experiments were carried out entirely in the glove box system according to the following procedure: after preparation of the electrodes and chemicals for the electrolyte, the GCC was filled with the salt mixture and assembled in the tube furnace. After heating up the molten salt to $\sim 700 \mathrm{~K}$ under constant argon flow, the electrodes were introduced in the electrolyte. In selected experiments, titanium and vanadium metal were added to the salt mixture, as shown in Table 1, in which they were left to equilibrate for several hours. Cyclic voltammetry $(\mathrm{CV})$ was carried out over a wide potential range to study the electrochemical

Table 1 Compositions and concentrations of the investigated electrolyte systems

\begin{tabular}{lllll}
\hline & Electrolyte system & $\begin{array}{l}C_{\mathrm{E}}\left(\mathrm{VCl}_{3}\right) \\
(\mathrm{mol} \%)\end{array}$ & $\begin{array}{l}C_{\mathrm{E}}\left(\mathrm{TiCl}_{2}\right) \\
(\mathrm{mol} \%)\end{array}$ & $\begin{array}{l}\text { Metal } \\
\text { addi- } \\
\text { tion }\end{array}$ \\
\hline ES 1 & $\mathrm{LiCl}-\mathrm{KCl}-\mathrm{VCl}_{3}$ & 0.34 & - & - \\
$\mathrm{ES} \mathrm{2}$ & $\mathrm{LiCl}-\mathrm{KCl}-\mathrm{VCl}_{3}-\mathrm{TiCl}_{2}$ & 0.34 & 0.45 & - \\
$\mathrm{ES} \mathrm{3}$ & $\mathrm{LiCl}-\mathrm{KCl}-\mathrm{VCl}_{3}-\mathrm{V}$ & 0.34 & - & $\mathrm{V}$ \\
$\mathrm{ES} 4$ & $\mathrm{LiCl}-\mathrm{KCl}-\mathrm{VCl}_{3}-\mathrm{TiCl}_{2}-\mathrm{V}$ & 0.34 & 0.45 & $\mathrm{~V}$ \\
$\mathrm{ES} 5$ & $\mathrm{LiCl}-\mathrm{KCl}-\mathrm{VCl}_{3}-\mathrm{TiCl}_{2}-\mathrm{V}$ & 0.17 & 0.45 & $\mathrm{~V}$ \\
$\mathrm{ES} \mathrm{6}$ & $\mathrm{LiCl}-\mathrm{KCl}-\mathrm{VCl}_{3}-\mathrm{TiCl}_{2}-\mathrm{V}$ & 0.09 & 0.46 & $\mathrm{~V}$ \\
$\mathrm{ES} 7$ & $\mathrm{LiCl}-\mathrm{KCl}-\mathrm{VCl}_{3}-\mathrm{TiCl}_{2}-\mathrm{Ti}$ & 0.34 & 0.45 & $\mathrm{Ti}$ \\
\hline
\end{tabular}


reactions in the system and to determine the potential of chlorine evolution $E\left(\mathrm{Cl}_{2} / \mathrm{Cl}^{-}\right)$as an internal reference system [30]. CV was also applied in order to determine suitable potentials for the electrodeposition processes. In most cases, three consecutive CV scans were carried out and displayed in the corresponding figures. For practical reasons, in the case of Ti-V alloy deposition, the deposition potential $\left(E_{\mathrm{D}}\right)$ was related to the peak potential of the $\mathrm{V}^{2+} / \mathrm{V}$ couple $\left(E_{\mathrm{P}}\right.$ $\left.\left(\mathrm{V}^{2+} / \mathrm{V}\right)\right)$ as an internal reference point. These CV measurements were carried out with a scan rate $v=0.01 \mathrm{~V} \mathrm{~s}^{-1}$ immediately before any of the potentiostatic electrodeposition experiments that were performed for $30 \mathrm{~min}$.

\subsection{Characterization of the deposits}

After the electrodeposition experiments, the electrodes were cleaned in deionized water. The length of the deposits, corresponding to the effective immersion length $(L)$ during electrolysis, was measured by optical microscopy (Zeiss Stereo Discovery V12) for the calculation of the current density (i). The microstructures and morphologies of the cathodic deposits were investigated using Zeiss Ultra 55 scanning electron microscope (SEM), and the chemical composition of the surface of all cathodic deposits was determined using energy-dispersive X-ray spectroscopy (EDS). Cross sections of selected deposits were prepared by focused ion beam (FIB) in a FEI Helios Nanolab 600i dual beam (electron and $\mathrm{Ga}^{+}$) microscope. Selected cathodic deposits were analysed by a Philips Tecnai F30 transmission electron microscope (TEM), for which lamellae were also prepared by FIB. Selected area electron diffraction (SAED) was used to identify the phases present in the deposits, and the local chemical composition of the cross sections of the deposits was measured by EDS within the TEM system.

\subsection{Thermodynamic computations}

Thermodynamic calculations were carried out to assess the fractions and compositions of the equilibrium phases of the Ti-V alloys for comparison with the experimental results. For this purpose, the software ThermoCalc Version 2018b was used with the database TCTI: TCS Ti- and TiAl alloys.

\section{Results}

\subsection{Electrochemical measurements}

$\mathrm{CV}$ experiments have been carried out in all selected electrolyte systems (Table 1) to determine the potential of the $\mathrm{QRE}\left(E_{\mathrm{QRE}}\right)$, which is a function of the electrolyte composition and the metal added to the electrolyte (Fig. 1), following the concept of the "internal reference system"

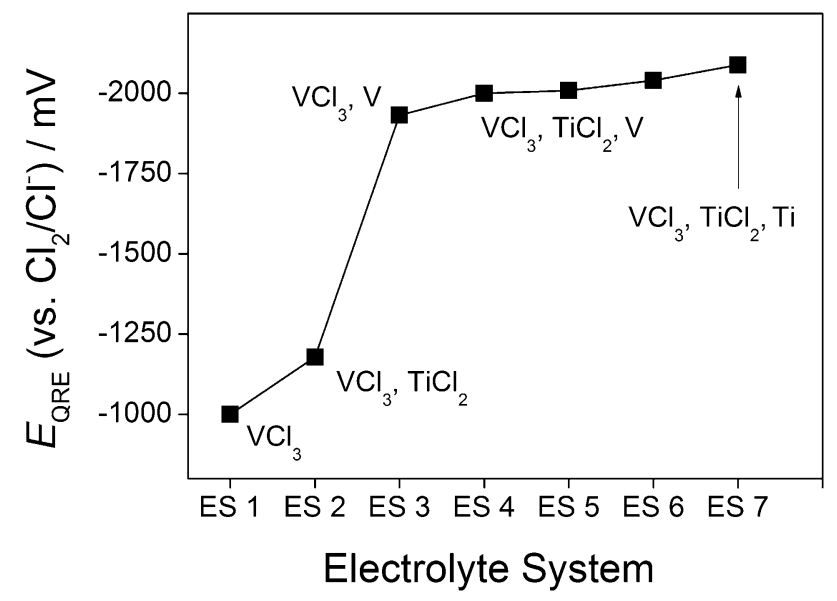

Fig. 1 Comparison of the electrode potential of the $E_{\mathrm{QRE}}$ related to $E\left(\mathrm{Cl}_{2} / \mathrm{Cl}^{-}\right)$in the different electrolyte systems.

[30]. The potential $E_{\mathrm{QRE}}$ in $(\mathrm{LiCl}-\mathrm{KCl})_{(\mathrm{eut} .)}-\mathrm{VCl}_{3}-\mathrm{TiCl}_{2}$ (ES 2) is ca. $-1180 \mathrm{mV}$ vs. $\mathrm{Cl}_{2} / \mathrm{Cl}^{-}$, i.e., a bit more negative due to the presence of titanium ions than that of the $(\mathrm{LiCl}-\mathrm{KCl})_{(\text {eut.) }}-\mathrm{VCl}_{3}(\mathrm{ES} 1$, investigated in a previous study [26]) which is ca. $-1000 \mathrm{mV}$ vs. $\mathrm{Cl}_{2} / \mathrm{Cl}^{-}$.

Titanium ions slightly change $E_{\mathrm{QRE}}$, while the more recognizable shift in the potential occurs due to the addition of $\mathrm{V}$ metal to the investigated systems (ES 3 - ES 6). Also the potential $E_{\mathrm{QRE}}$ of $(\mathrm{LiCl}-\mathrm{KCl})_{(\text {eut. }}-\mathrm{VCl}_{3}-\mathrm{TiCl}_{2}-\mathrm{V}$ (ES 4) was ca. $-2000 \mathrm{mV}$, i.e., more negative than that of $(\mathrm{LiCl}-\mathrm{KCl})_{(\text {eut.) }}-\mathrm{VCl}_{3}-\mathrm{V}(\mathrm{ES} \mathrm{3})$. Based on this and according to our previous work [26], vanadium metal reacted by comproportionation with the trivalent vanadium ions (Eq. 1) showing that the potential $E_{\mathrm{QRE}}$ is mainly determined by the electrode potential of the $\mathrm{V} / \mathrm{V}^{2+}$ couple $\left(E\left(\mathrm{~V} / \mathrm{V}^{2+}\right)\right)$.

$2 \mathrm{~V}^{3+}+\mathrm{V} \rightarrow 3 \mathrm{~V}^{2+}$

Within the systems $(\mathrm{LiCl}-\mathrm{KCl})_{(\text {eut. })}-\mathrm{VCl}_{3}-\mathrm{TiCl}_{2}-\mathrm{V}$ (ES 4-ES 6) decreasing the $\mathrm{VCl}_{3}$ concentration caused a slight potential shift of the QRE to more negative values because of the (relatively) increasing influence of the titanium ions. Correspondingly, the addition of titanium metal in case of $(\mathrm{LiCl}-\mathrm{KCl})_{(\text {eut. })}-\mathrm{VCl}_{3}-\mathrm{TiCl}_{2}-\mathrm{Ti}$ (ES 7) caused a further shift of $E_{\mathrm{QRE}}$ to more negative potentials (ca. $-2090 \mathrm{mV}$ vs. $\mathrm{Cl}_{2} /$ $\mathrm{Cl}^{-}$) due to even higher concentrations of titanium ions and $E_{\mathrm{QRE}}$ is mainly determined by the $\mathrm{Ti} / \mathrm{Ti}^{2+}$ couple.

The $\mathrm{CV}$ experiments in $(\mathrm{LiCl}-\mathrm{KCl})_{(\text {eut.) }}-\mathrm{VCl}_{3}-\mathrm{TiCl}_{2}$ without metal addition (ES 2) were qualitatively similar to those with $\mathrm{V}$ metal addition, although the absolute values of the measured potentials differed because of the changing potential of the QRE (see above).

Besides the potential shift, the peaks in $(\mathrm{LiCl}-\mathrm{KCl})_{(\text {eut.) }}-\mathrm{VCl}_{3}-\mathrm{TiCl}_{2}-\mathrm{Ti}(\mathrm{ES} \mathrm{7})$ corresponding to 
the oxidation and reduction reactions of the vanadium ions were strongly reduced and disappeared completely after a few hours. We assume that a galvanic replacement reaction [31] occurred (Eq. 2). This conclusion will be substantiated by the results presented in Sect. 3.2.

$2 \mathrm{~V}^{3+}+3 \mathrm{Ti} \rightarrow 3 \mathrm{Ti}^{2+}+2 \mathrm{~V}$

$\mathrm{CV}$ carried out in $(\mathrm{LiCl}-\mathrm{KCl})_{(\text {eut. })}-\mathrm{VCl}_{3}-\mathrm{TiCl}_{2}-\mathrm{V}$ (ES 4) revealed the presence of $\mathrm{Ti}$ and $\mathrm{V}$ ions, and all typical electrochemical reactions of both elements could be recognized (Fig. 2). The shapes of the CV peaks of the redox reactions are found to be similar to those of the single-element systems (with $\mathrm{VCl}_{3}$ in the case of ES 1 and $\mathrm{ES} 3$ and with $\mathrm{TiCl}_{2}$ in a previous study [28]). The steep reduction peak of the reaction $\left(\mathrm{Ti}^{4+} / \mathrm{Ti}^{3+}\right)$ can be explained by the formation $(\mathrm{O} 3)$

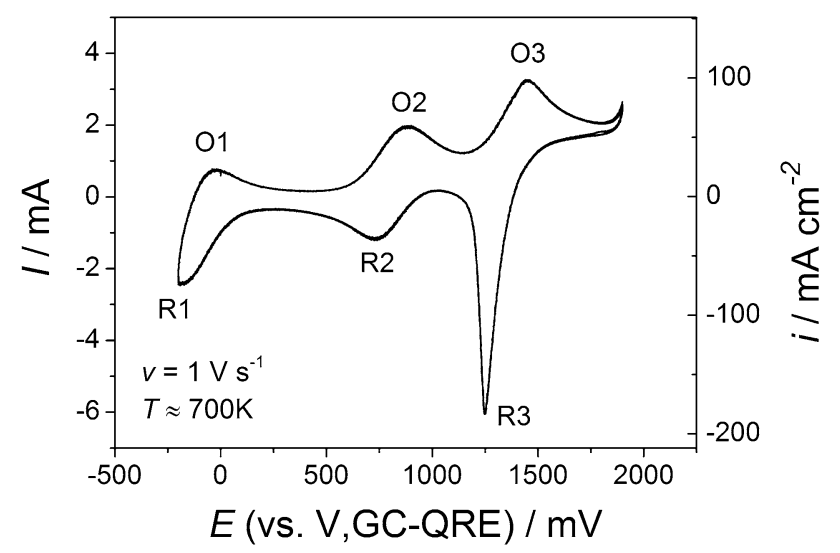

Fig. $2 \mathrm{CV}$ recorded in $(\mathrm{LiCl}-\mathrm{KCl})_{(\text {eut. }}-0.34 \mathrm{~mol} \% \mathrm{VCl}_{3}-0.45 \mathrm{~mol} \%$ $\mathrm{TiCl}_{2}-\mathrm{V}$ melt (ES 4) using a W electrode at $700 \mathrm{~K}$ with a scan rate of $1 \mathrm{~V} \mathrm{~s}^{-1}$. A metallic V-wire was added to the electrolyte and had contact to the GC-crucible (V,GC-QRE).

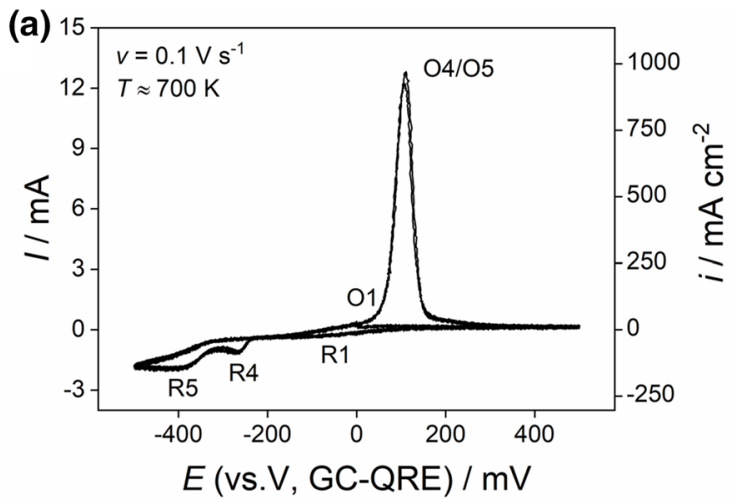

Fig. $3 \mathrm{CV}$ recorded in $(\mathrm{LiCl}-\mathrm{KCl})_{(\text {eut. }}-0.34 \mathrm{~mol} \% \mathrm{VCl}_{3}-0.45 \mathrm{~mol} \%$ $\mathrm{TiCl}_{2}-\mathrm{V}$ (ES 4) melt using W working electrode at $700 \mathrm{~K}$ with scan rates of $0.1 \mathrm{~V} \mathrm{~s}^{-1}$ (a) and $0.01 \mathrm{~V} \mathrm{~s}^{-1}$ (b). The anodic scan is highlighted (red) in the case of the $\mathrm{CV}$ recorded with $v=0.01 \mathrm{~V} \mathrm{~s}^{-1}$ to and dissolution (R3) of the insoluble product $\mathrm{K}_{2} \mathrm{TiCl}_{6}$ [32], whereas $\mathrm{V}^{2+} / \mathrm{V}^{3+}(\mathrm{O} 2 / \mathrm{R} 2)$ and $\mathrm{Ti}^{2+} / \mathrm{Ti}^{3+}(\mathrm{R} 1 / \mathrm{O} 1)$ seem to be reversible reactions as was also observed in the singleelement systems [28, 26].

Two current waves belonging to electrochemical metal deposition were observed that can be assigned to the reduction of $\mathrm{V}^{2+}$ and $\mathrm{Ti}^{2+}$ (Fig. 3, R4 and R5). The observation of separated current peaks is, however, no proof that pure vanadium can be deposited independent from titanium with a ca. $0.2 \mathrm{~V}$ more negative deposition potential [33], as will be considered in Sect. 3.2.

The CV measurement in Fig. 3a shows only one dissolution peak $(\mathrm{O} 4 / \mathrm{O} 5)$ and two reduction peaks $(\mathrm{R} 4, \mathrm{R} 5)$ related to the deposition processes. Only at lower scan rates (e.g., $v=0.01 \mathrm{~V} \mathrm{~s}^{-1}$, Fig. 3b), two or even more distinguishable dissolution peaks could be identified.

A comparison of experiments in the different electrolyte systems indicates that the peak potential related to anodic dissolution depends on the electrolyte concentration (Fig. 4). In both systems with ions of only one metal (i.e., ES 3 with $\mathrm{V}^{2+}$ and ES 7 with $\mathrm{Ti}^{2+}$ after the ions reacted with the added Ti metal), we find similar potential differences (ca. $250 \mathrm{mV}$ ) between the first peak potentials of deposition (R4 or R5) and dissolution (O4 or O5). The potential differences in the systems with ions of both $\mathrm{Ti}$ and $\mathrm{V}$ are much larger even if we relate the dissolution potential to $E_{\mathrm{P}}\left(\mathrm{V}^{2+} / \mathrm{V}\right)$ to the more noble metal.

The dissolution behaviour is also influenced by the actual composition of the $(\mathrm{LiCl}-\mathrm{KCl})_{(\text {eut.) }}-\mathrm{VCl}_{3}-\mathrm{TiCl}_{2}-\mathrm{V}$ electrolyte system: the peak potential difference between $\mathrm{R} 4$ and $\mathrm{O} 4 /$ $\mathrm{O} 5$ increases with higher $\mathrm{VCl}_{3}$ concentrations from ca. 300 $\mathrm{mV}$ for $0.09 \mathrm{~mol} \%$ up to $>370 \mathrm{mV}$ for $0.34 \mathrm{~mol} \%$ (Fig. 4b). Besides the shift of the peak to more positive potentials, the dissolution peaks become narrower with increasing $\mathrm{VCl}_{3}$ concentration; thus, the full width at half maximum

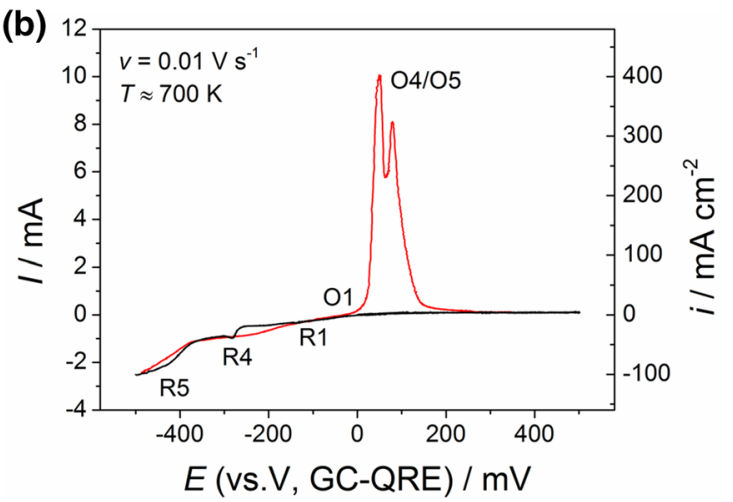

allow a distinction of the current progression in the region of the crossover. A metallic V-wire was added to the electrolyte and had contact to the GC-crucible (V,GC-QRE). 
Fig. 4 a Comparison of $\mathrm{CV}$ measurements recorded in $(\mathrm{LiCl}-\mathrm{KCl})_{(\text {eut. }}-0.09 \mathrm{~mol} \%$ $\mathrm{VCl}_{3}-0.46 \mathrm{~mol} \% \mathrm{TiCl}_{2}-\mathrm{V}$ (CV scan A, ES 6), (LiCl$\mathrm{KCl})_{\text {(eut.) }}-0.34 \mathrm{~mol}^{2} \mathrm{VCl}_{3}-\mathrm{V}$ (CV scan B, ES 3) [26] and $(\mathrm{LiCl}-\mathrm{KCl})_{(\text {eut. }}-0.34 \mathrm{~mol} \%$ $\mathrm{VCl}_{3}-0.45 \mathrm{~mol} \% \mathrm{TiCl}_{2}-\mathrm{Ti}$ (CVscan C, ES 7) with a scan rate of $0.1 \mathrm{~V} \mathrm{~s}^{-1}$. The $\mathrm{CV}$ measurements are displaced for comparison (abscissa and ordinate). b Comparison of CV measurements in the $(\mathrm{LiCl}-$ $\mathrm{KCl})_{(\text {eut.) }}-\mathrm{VCl}_{3}-\mathrm{TiCl}_{2}-\mathrm{V}$ (ES 4, lower CV scan and ES 6, upper $\mathrm{CV}$ scan) with different concentrations of $\mathrm{VCl}_{3}$. The potentials are related to the peak potential $E_{\mathrm{P}}\left(\mathrm{V}^{2+} / \mathrm{V}\right)$. (a)

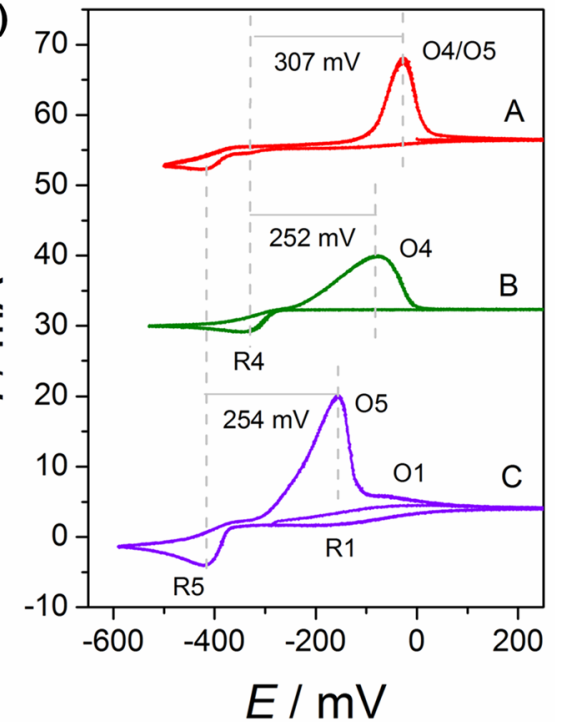

(b)

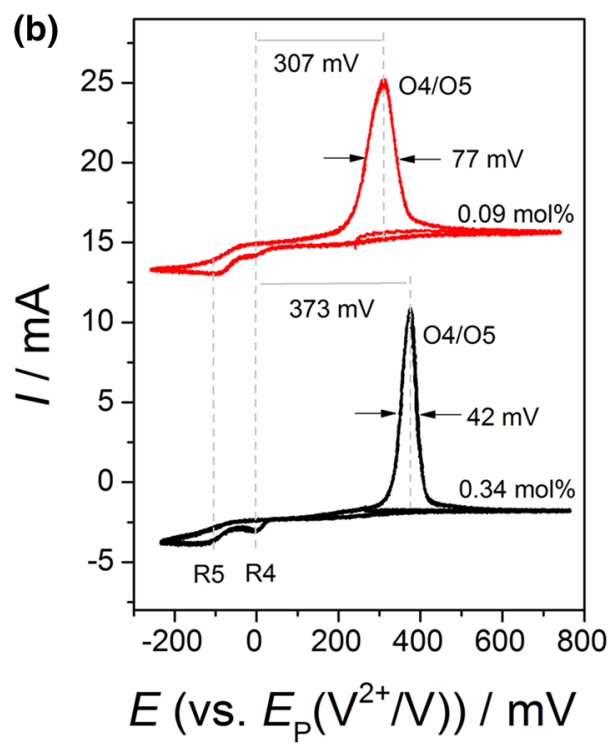

decreases from ca. $77 \mathrm{mV}$ for $0.09 \mathrm{~mol} \% \mathrm{VCl}_{3}$ to ca. $42 \mathrm{mV}$ for $0.34 \mathrm{~mol} \% \mathrm{VCl}_{3}$.

\subsection{Characterization of the titanium-vanadium deposits}

\subsubsection{Composition}

Electrodeposition experiments carried out in $(\mathrm{LiCl}-\mathrm{KCl})_{(\text {eut.) }}-\mathrm{VCl}_{3}-\mathrm{TiCl}_{2}$ without any metal addition (ES 2 ) were unstable and did not provide compact coatings. The addition of Ti, already described in the previous Sect. 3.1 with respect to the observed ionic species, led to an impoverishment of vanadium ions within a few hours according to Eq. 2 and was therefore not a suitable method to realize a stable condition for $\mathrm{Ti}-\mathrm{V}$ deposition. While the coating obtained from the electrolyte with titanium metal (ES 7) just after melting consisted of ca. 89 at $\%$ Ti and ca. 11 at $\% \mathrm{~V}$, the coating obtained after an interruption of one day contained very low amounts of vanadium $(<1$ at $\%)$.

As more stable conditions were found in $(\mathrm{LiCl}-\mathrm{KCl})_{\text {(eut.) }}-\mathrm{TiCl}_{2}-\mathrm{VCl}_{3}-\mathrm{V}$ (ES 4-ES 6), a systematic variation of deposition potential and electrolyte concentration was realized in this electrolyte system. For the comparison of electrolyte concentration and composition of the deposit, the corresponding values were expressed as molar ratios $\left(\chi_{\mathrm{E}}\right.$ molar ratio in electrolyte, $\chi_{\mathrm{D}}$ molar ratio in deposit) of vanadium to titanium (Fig. 5). The molar ratio $\chi_{\mathrm{E}}$ was calculated based on the assumption that divalent vanadium ions were generated according to Eq. 1.

At positive deposition potentials $\left(E_{\mathrm{D}}-E_{\mathrm{P}}\left(\mathrm{V}^{2+} / \mathrm{V}\right)>0\right.$ $\mathrm{mV})$ vanadium-rich deposits with molar ratios $\chi_{\mathrm{D}}(\mathrm{V} / \mathrm{Ti})$ up to 10 were obtained, although pure vanadium could not be deposited. In $(\mathrm{LiCl}-\mathrm{KCl})_{(\text {eut. })}-0.45 \mathrm{~mol} \% \mathrm{TiCl}_{2}-0.34$

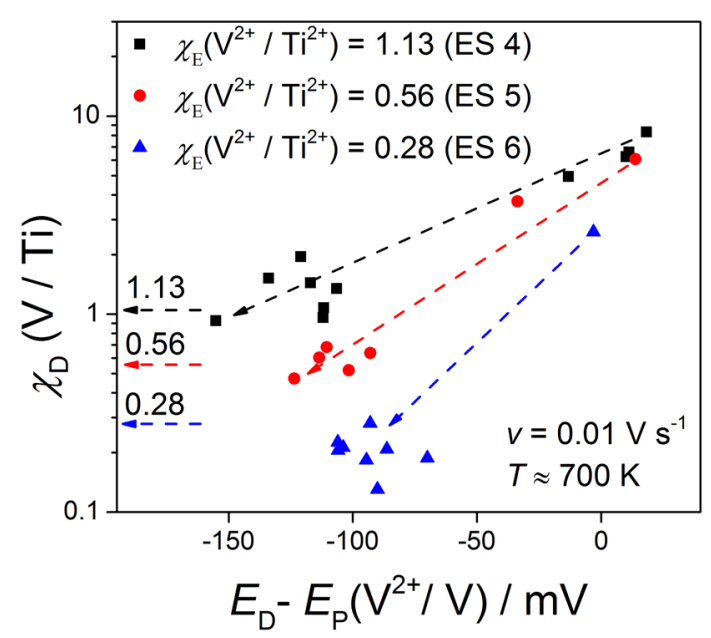

Fig. 5 Molar ratio $\chi_{\mathrm{D}}(\mathrm{V} / \mathrm{Ti})$ of the deposit as a function of electrodeposition potential $E_{\mathrm{D}}$ (related to $E_{\mathrm{P}}\left(\mathrm{V}^{2+} / \mathrm{V}\right)$ determined in preceding $\mathrm{CV}$ measurements with $v=0.01 \mathrm{~V} \mathrm{~s}^{-1}$ ) for different compositions of the electrolyte system $(\mathrm{LiCl}-\mathrm{KCl})_{(\text {eut. })}-\mathrm{VCl}_{3}-\mathrm{TiCl}_{2}-\mathrm{V}$. The molar ratio of $\chi_{\mathrm{E}}\left(\mathrm{V}^{2+} / \mathrm{Ti}^{2+}\right)$ was calculated with the assumption that all $\mathrm{V}^{3+}$ reacted to $\mathrm{V}^{2+}$.

mol\% $\mathrm{VCl}_{3}-\mathrm{V}$ (ES 4 with $\chi_{\mathrm{E}}=1.13$ ), for example, a vanadium-rich deposit with 90 at $\% \mathrm{~V}$ was obtained at $E_{\mathrm{D}}=$ $-265 \mathrm{mV}$ (corresponding $E_{\mathrm{D}}-E_{\mathrm{P}}\left(\mathrm{V}^{2+} / \mathrm{V}\right)=+18 \mathrm{mV}$ ).

Electrodeposition at a potential of $E_{\mathrm{D}}=-300 \mathrm{mV}$, i.e., in between the peaks $E_{\mathrm{P}}\left(\mathrm{V}^{2+} / \mathrm{V}\right)$ and $E_{\mathrm{P}}\left(\mathrm{Ti}^{2+} / \mathrm{Ti}\right)$ determined during the preceding $\mathrm{CV}$ experiments, resulted in titanium contents around 20 at $\%\left(\chi_{\mathrm{D}}(\mathrm{V} / \mathrm{Ti}) \approx 4\right)$. At even more negative potentials $\left(E_{\mathrm{D}}=-444 \mathrm{mV}\right)$, the titanium content of the coating was ca. 40 at $\%\left(\chi_{\mathrm{D}}(\mathrm{V} / \mathrm{Ti}) \approx 1.5\right)$. In this electrolyte system, titanium contents only up to ca. 50 at $\%$ were realized. According to Fig. 5 at sufficiently negative applied 
potentials, the molar ratios $\chi_{\mathrm{D}}$ and $\chi_{\mathrm{E}}$ are similar, i.e., at potentials which are close to the limiting current condition for titanium deposition. This is indicated by the arrows corresponding to $\chi_{\mathrm{E}}$. The diagram clearly illustrates the relationships between applied potential, bath concentration and composition of the deposit. However, it also demonstrates that there is a large scatter and further investigations are necessary to improve reproducibility and knowledge to realize certain alloy compositions. Nonetheless, a generalization of this observation, i.e., choosing electrolytes with the same molar ratio as the desired deposit, is not necessarily a successful approach $[34,35]$.

\subsubsection{Morphology}

The electrolyses in $(\mathrm{LiCl}-\mathrm{KCl})_{(\text {eut. }}-\mathrm{VCl}_{3}-\mathrm{TiCl}_{2}$ without any metal addition (ES 2) were unstable, and the results are not presented here. With titanium metal addition (ES 7), deposits of different morphologies were produced (Fig. 6): in the first electrodeposition experiment carried out shortly after melting the electrolyte a thick coating $(\approx 31 \mu \mathrm{m})$ was obtained (Fig. 6a, b). The densely grown coating had a cauliflower-like morphology and exhibited also large globular growth failures. The deposit obtained after an interruption of one day while the electrolyte was constantly at $T \approx 700 \mathrm{~K}$ was a more compact $39-\mu \mathrm{m}$-thick coating with large faceted crystals (Fig. 6c, d) that looks very similar to the pure titanium deposits from $\mathrm{LiCl}-\mathrm{KCl}-\mathrm{TiCl}_{2}[28,20]$. Interestingly, also the amount of growth failures, such as globular crystal agglomerations, was strongly reduced.

Various deposit morphologies were obtained in the $(\mathrm{LiCl}-\mathrm{KCl})_{(\text {eut. }}-0.34 \mathrm{~mol} \% \mathrm{VCl}_{3}-0.45 \mathrm{~mol} \% \mathrm{TiCl}_{2}-\mathrm{V}$ (ES 4) depending on the deposition potential: vanadium-rich deposits (ca. 90 at\%) grown at $E_{\mathrm{D}}=-265 \mathrm{mV}$ (i.e., $E_{\mathrm{D}}-E_{\mathrm{P}}$ $\left.\left(\mathrm{V}^{2+} / \mathrm{V}\right)=+16 \mathrm{mV}\right)$ exhibited large dendrites (even with length $>100 \mu \mathrm{m}$ ) grown on a thin dense layer (Fig. 7a, d). Electrodeposition at a potential of $E_{D}=-300 \mathrm{mV}$, which is between the peaks $E_{\mathrm{P}}\left(\mathrm{V}^{2+} / \mathrm{V}\right)$ and $E_{\mathrm{P}}\left(\mathrm{Ti}^{2+} / \mathrm{Ti}\right)$ did not show massive dendrite grows but incoherent globular structures (Fig. 7b, e). At even more negative potentials $\left(E_{\mathrm{D}}=-444\right.$ $\left.\mathrm{mV} ; E_{\mathrm{D}}-E_{\mathrm{P}}\left(\mathrm{V}^{2+} / \mathrm{V}\right)=-134 \mathrm{mV}\right)$, the coating with 40 at $\%$ Ti was $\sim 38 \mu \mathrm{m}$ thick with comparatively few growth failures (Fig. 7c, f). Similar results were also obtained in the electrolyte systems with lower vanadium concentrations in the electrolyte, i.e., dendritic structures at $E_{\mathrm{D}}-E_{\mathrm{p}}\left(\mathrm{V}^{2+} / \mathrm{V}\right) \geq 0 \mathrm{mV}$ and more dense coatings with cauliflower-like morphologies at $E_{\mathrm{D}}-E_{\mathrm{p}}\left(\mathrm{V}^{2+} / \mathrm{V}\right)<<0 \mathrm{mV}$.

\subsubsection{Microstructure}

TEM investigations of deposits from the $(\mathrm{LiCl}-\mathrm{KCl})_{(\text {eut. }}-0.34 \mathrm{~mol} \% \mathrm{VCl}_{3}-0.45 \mathrm{~mol} \% \mathrm{TiCl}_{2}-\mathrm{V}(\mathrm{ES}$ 4; deposit in Fig. 7f) revealed a fine feathery microstructure and allowed to distinguish individual crystals with grain sizes in the range of several $100 \mathrm{~nm}$ that are elongated in growth direction (Fig. 8a).

The deposit from $\left.(\mathrm{LiCl}-\mathrm{KCl})_{(\text {eut. }}\right)-0.09 \mathrm{~mol} \% \mathrm{VCl}_{3}-0.46$ $\mathrm{mol} \% \mathrm{TiCl}_{2}-\mathrm{V}$ (ES 6) with around 11 at\% vanadium was even finer (Fig. 8d). This was also manifested during electron diffraction (Fig. 8b, e) because the Debye-Scherrer rings of measurements carried out with same beam size are much spottier in the case of the Ti-V alloy with a higher vanadium concentration (ca. 60 at\%, i.e., Ti-60V, Fig. 8b). SAED (Fig. 8b, c) demonstrated that this Ti-60V alloy consisted predominantly of body-centred cubic $\beta$ phase (space group: $\mathrm{Im}-3 \mathrm{~m})$. Further diffraction experiments carried out
Fig. 6 SEM images $(\mathbf{a}, \mathbf{b})$ of the first cathodic deposit obtained from $(\mathrm{LiCl}-\mathrm{KCl})_{(\text {eut.) }}-0.34$ $\mathrm{mol} \% \mathrm{VCl}_{3}-0.45 \mathrm{~mol} \% \mathrm{TiCl}_{2}-$ Ti (ES 7) at $T=700 \mathrm{~K}, t=30$ $\min , E_{\mathrm{D}}=-160 \mathrm{mV}$ vs. Ti, GC-QRE. SEM images (c, d) of deposit obtained in the same electrolyte after an interruption of one day at $T=700 \mathrm{~K}, t=30$ $\min , E_{\mathrm{D}}=-100 \mathrm{mV}$ vs. Ti, GC-QRE.
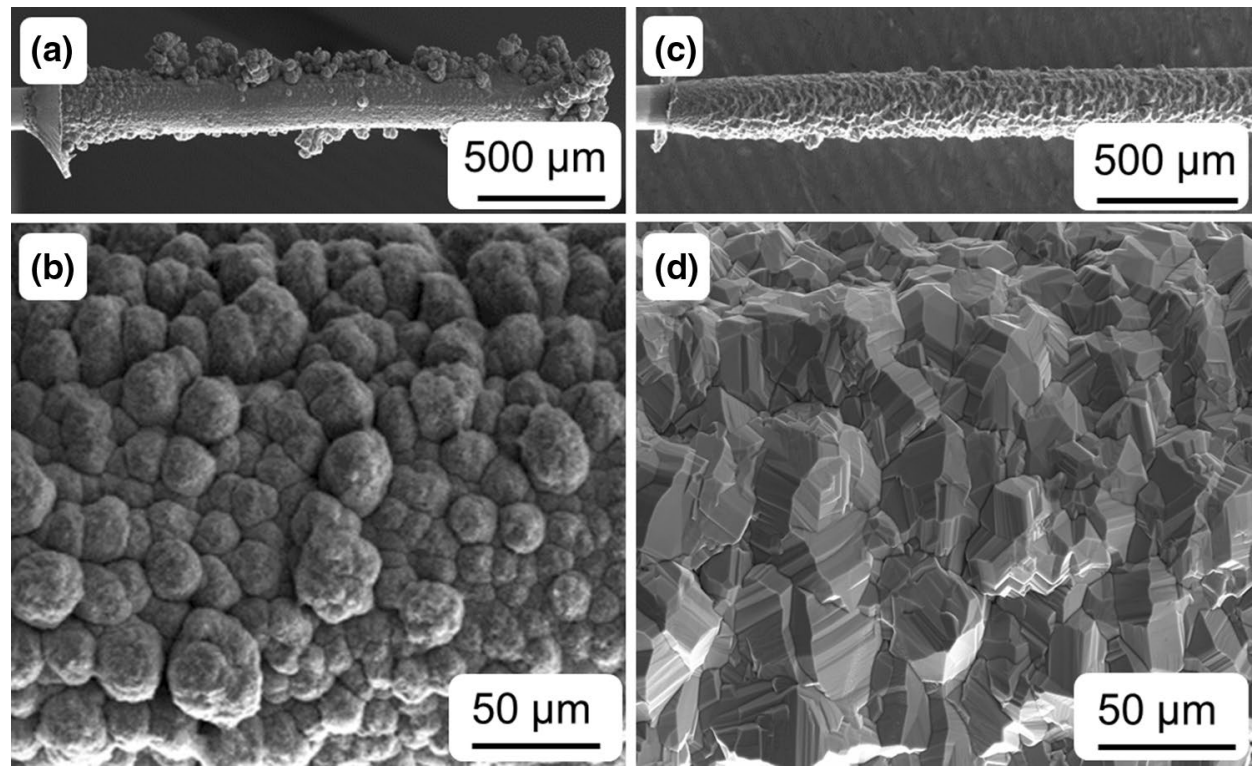
at individual crystals (Fig. 9) also revealed the presence of hexagonal $\omega$ phase (space group: $\mathrm{P} 6 / \mathrm{mmm}$ ). In contrast, the ultrafine titanium-rich alloy (Ti-11 at\% V, i.e., Ti-11V) consists of $\beta-(\mathrm{V}, \mathrm{Ti})$ and $\alpha-\mathrm{Ti}$ (space group: $\left.\mathrm{P}_{3} / \mathrm{mmc}\right)$.

In addition, FIB was used for the preparation of highquality cross sections (Fig. 10) from the Ti-60V deposit (produced from $(\mathrm{LiCl}-\mathrm{KCl})_{(\text {eut. }}-0.34 \mathrm{~mol} \% \mathrm{VCl}_{3}-0.45$ mol\% $\mathrm{TiCl}_{2}-\mathrm{V}$, ES 4) as well as $\mathrm{Ti}-11 \mathrm{~V}$ deposits (from $(\mathrm{LiCl}-\mathrm{KCl})_{\text {(eut.) }}-0.09 \mathrm{~mol} \% \mathrm{VCl}_{3}-0.46 \mathrm{~mol} \% \mathrm{TiCl}_{2}-\mathrm{V}$, ES 6) allowing to examine the interface between $\mathrm{Ti}-\mathrm{V}$ alloy and substrate (tungsten wire) as well as the volume density of the deposit. The samples appear pore free and the interface to the tungsten wire does not show any electrolyte inclusions (Fig. 10a, c). The investigation of Ti-60V also demonstrated how the cauliflower-like morphology, which had been observed in SEM (Fig. 7b), developed during the electrodeposition process (Fig. 10b): a very fine structure started to grow at the interface and after ca. $5 \mu \mathrm{m}$ a change of the principle growth direction took place in the middle of the sample. This caused a globular growth failure that was responsible for the cauliflower-like morphology. In spite of a layer thickness of ca. $20 \mu \mathrm{m}$, the grain size remains very fine, a finding that is in contrast to electrodeposition of pure titanium [20] or vanadium [26] where large faceted crystals and the crystal size often close to the layer thickness were found.

The corresponding characterization carried out with the Ti-11V alloy allowed to distinguish the $\beta$ and $\alpha$ phase in the microstructure. Very fine bright crystals assigned to the $\beta$ phase were observed (Fig. 10d), in which the heavier vanadium is accumulated. EDS carried out in TEM demonstrated areas with an accumulation of vanadium. In these areas ( $\beta$ phase), up to approx. 18 at\% vanadium and in the titaniumrich regions ( $\alpha$ phase) only ca. 7 at $\%$ were measured. The average vanadium content determined in this area (ca. 13 at $\%$ ) is slightly higher than the value of ca. 11 at\% measured by EDS in the SEM.

\subsection{Inspection of solidified electrolyte}

In the electrolyte $(\mathrm{LiCl}-\mathrm{KCl})_{(\text {eut. }}-0.34 \mathrm{~mol} \% \mathrm{VCl}_{3}-0.45$ mol\% $\mathrm{TiCl}_{2}$ (ES 2), a greyish pink colour was observed (Fig. 11a), which indicates the presence of predominantly trivalent species, especially $\mathrm{V}^{3+}$ ions from $\mathrm{VCl}_{3}$ salt. The electrolyte system with titanium metal addition (ES 7) shows a green colour (Fig. 11b), a further proof that the trivalent
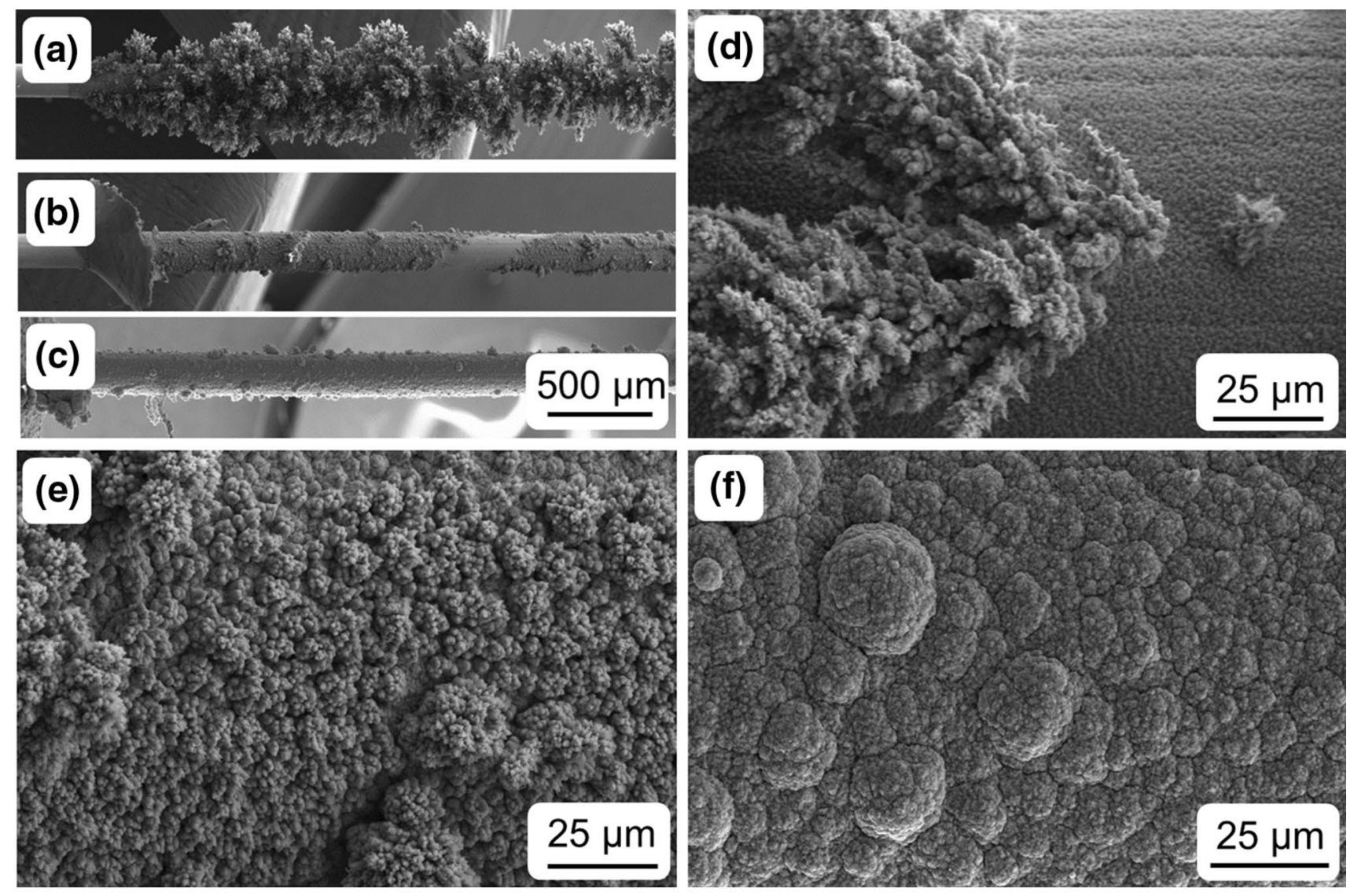

Fig. 7 Morphology SEM images of the cathodic deposit obtained from $(\mathrm{LiCl}-\mathrm{KCl})_{(\mathrm{eut} .)}-0.34 \mathrm{~mol} \% \mathrm{VCl}_{3}-0.45 \mathrm{~mol}^{2} \mathrm{TiCl}_{2}-\mathrm{V} \mathrm{melt}(\mathrm{ES} 4)$ at $T=700 \mathrm{~K}$. The experiments were carried out at $E_{\mathrm{D}}=-265 \mathrm{mV}(\mathbf{a}, \mathbf{d}), E_{\mathrm{D}}=-300 \mathrm{mV}(\mathbf{b}, \mathbf{e})$ and $-444 \mathrm{mV}(\mathbf{c}, \mathbf{f}) \mathrm{vs}$. V, GC-QRE. 

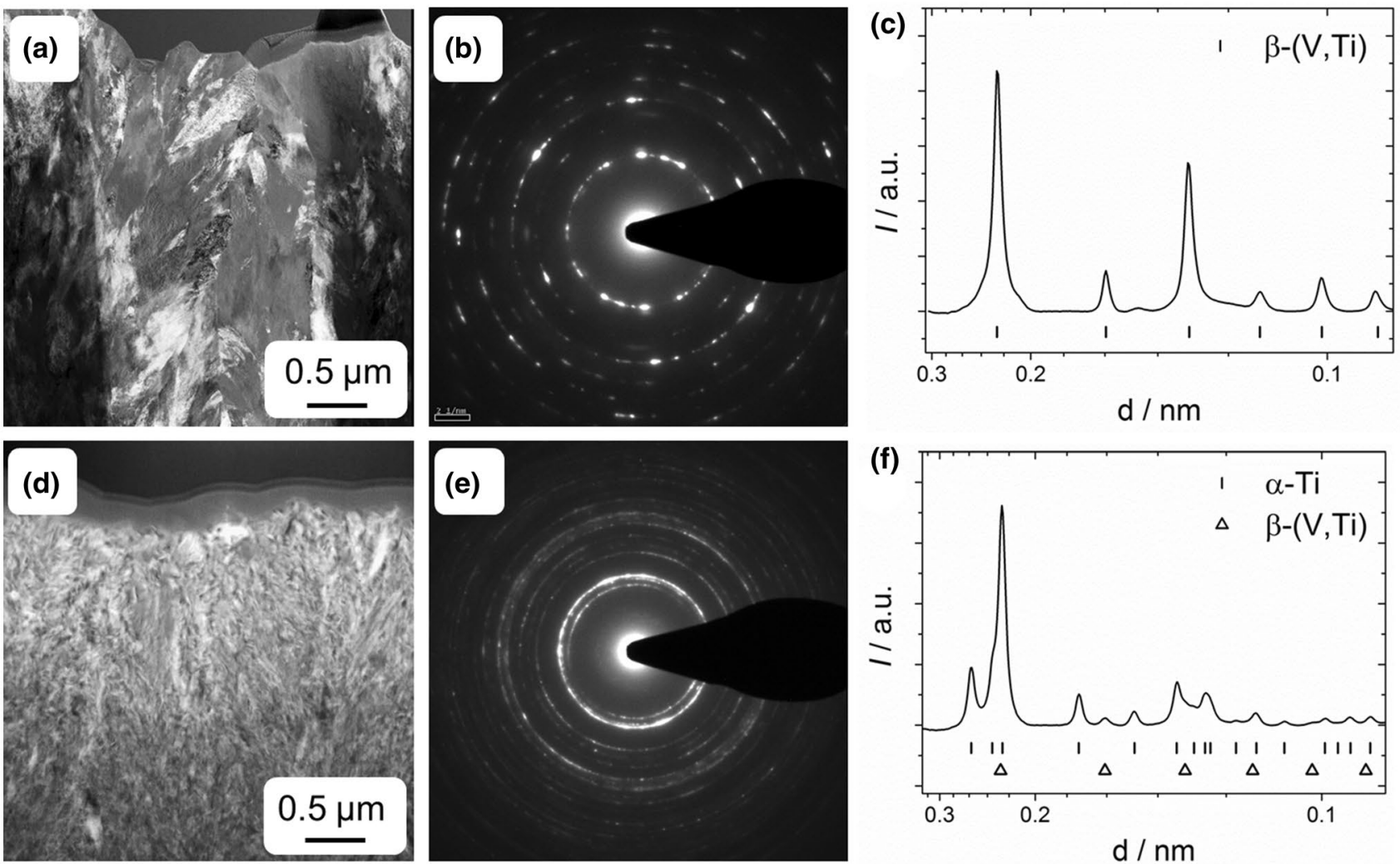

Fig. 8 TEM dark field image a SAED pattern $\mathbf{b}$ and corresponding diffractogram $\mathbf{c}$ of a Ti-V alloy deposited from $(\mathrm{LiCl}-\mathrm{KCl})_{(\text {eut.) }}-0.34$ $\mathrm{mol} \% \mathrm{VCl}_{3}-0.45 \mathrm{~mol} \% \mathrm{TiCl}_{2}-\mathrm{V}$ (ES 4). The material consists mainly of $\beta$-(V,Ti) (bcc, space group Im-3m). TEM dark field image (d),
SAED (e) and corresponding diffractogram (f) of Ti-V alloy deposited from $(\mathrm{LiCl}-\mathrm{KCl})_{\text {(eut.) }}-0.09 \mathrm{~mol} \% \mathrm{VCl}_{3}-0.46 \mathrm{~mol} \% \mathrm{TiCl}_{2}-\mathrm{V}$. The material consists of $\alpha-\mathrm{Ti}$ and $\beta-(\mathrm{V}, \mathrm{Ti})$.
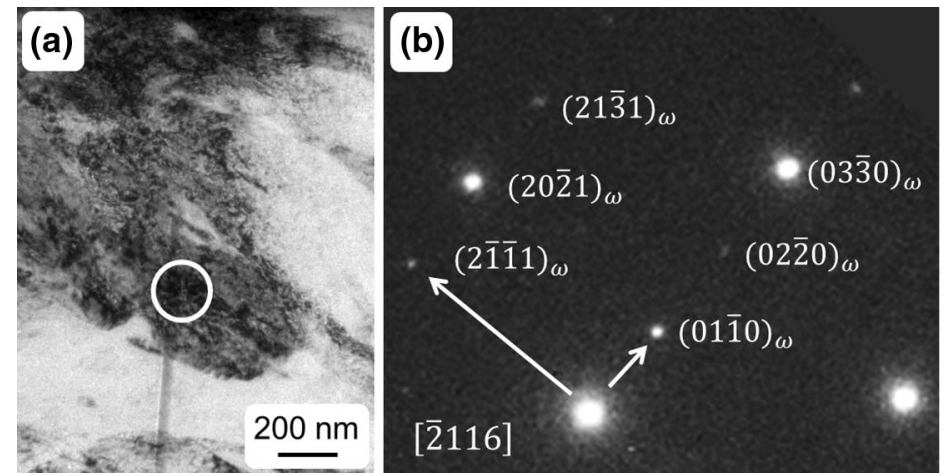

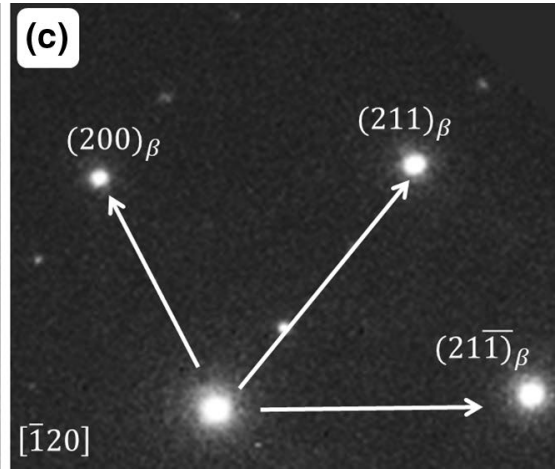

strating that the Ti-60 at $\% \mathrm{~V}$ alloy contains hexagonal $\omega$ phase, space group P6/mmm (b) besides $\beta$-(V,Ti), space group Im-3m (c).

\section{Discussion}

$\mathrm{CV}$ measurements indicate that independent $\mathrm{Ti}$ and $\mathrm{V}$ ions are present in the $(\mathrm{LiCl}-\mathrm{KCl})_{(\text {eut. })}-\mathrm{VCl}_{3}-\mathrm{TiCl}_{2}$ electrolyte system. The shapes of the oxidation and reduction reactions are very similar to those observed in the systems containing 
Fig. 10 Cross section a produced by FIB of a deposit from $(\mathrm{LiCl}-\mathrm{KCl})_{\text {(eut.) }}-0.34 \mathrm{~mol} \%$ $\mathrm{VCl}_{3}-0.45 \mathrm{~mol} \% \mathrm{TiCl}_{2}-\mathrm{V}$ metal at $E_{\mathrm{D}}=-350 \mathrm{mV}\left(E_{\mathrm{D}}-E_{\mathrm{P}}\right.$ $\left.\left(\mathrm{V}^{2+} / \mathrm{V}\right)=-111 \mathrm{mV}\right)$ showing $\mathrm{W}$-wire (lower part) and deposit (T-60V, upper part). Cross section b showing the microstructure of Ti-60V and a typical growth failure responsible for the cauliflower-like appearance of the coating. The white arrow points to the initiation of the growth failure. Cross section c of a deposit from ( $\mathrm{LiCl}-$ $\mathrm{KCl})_{\text {(eut.) }}-0.09 \mathrm{~mol} \% \mathrm{VCl}_{3}-0.46$ mol\% $\mathrm{TiCl}_{2}-\mathrm{V}$. Cross section $\mathbf{d}$ with biphasic $\alpha+\beta$ microstructure of the Ti-11V alloy.
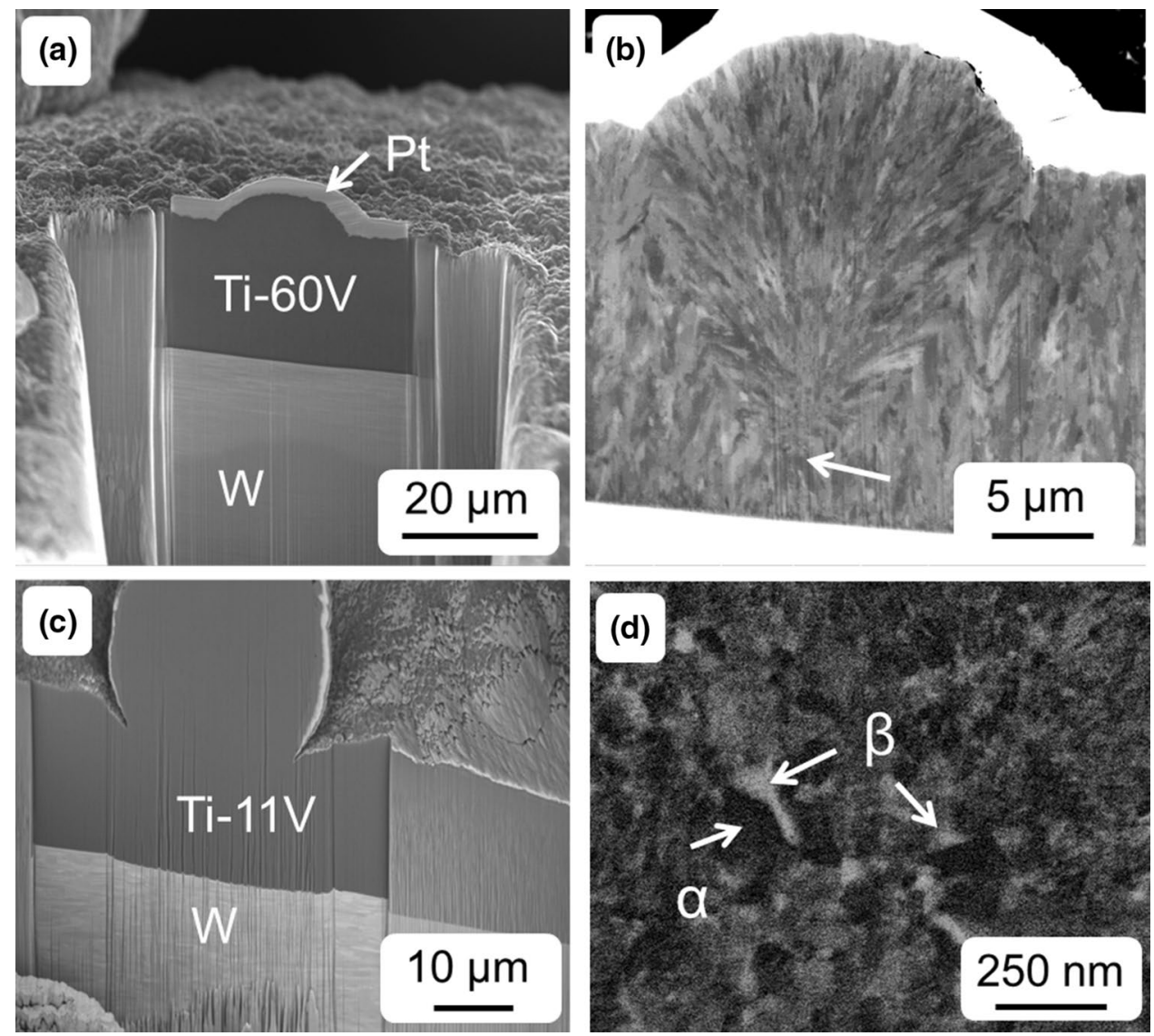

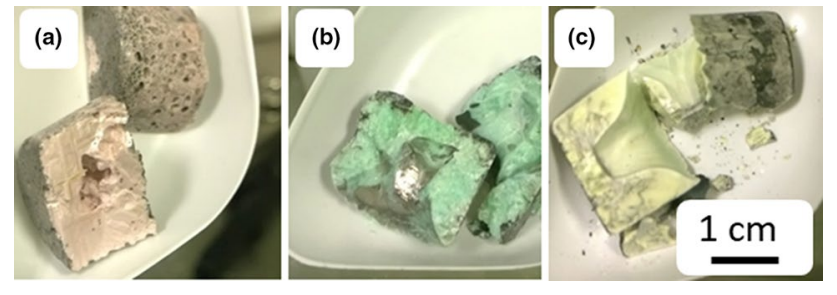

Fig. 11 Pieces of the solidified electrolytes after the deposition experiments: $(\mathrm{LiCl}-\mathrm{KCl})_{(\text {eut.) }}-0.34 \mathrm{~mol} \% \mathrm{VCl}_{3}-0.45 \mathrm{~mol}^{2} \mathrm{TiCl}_{2}$ (a, ES 2). $(\mathrm{LiCl}-\mathrm{KCl})_{(\text {eut.) }}-0.34 \mathrm{~mol} \% \mathrm{VCl}_{3}-0.45 \mathrm{~mol} \% \mathrm{TiCl}_{2}-\mathrm{Ti}$ (b, ES 7). $(\mathrm{LiCl}-\mathrm{KCl})_{(\text {eut.) }}-0.34 \mathrm{~mol} \% \mathrm{VCl}_{3}-0.45 \mathrm{~mol} \% \mathrm{TiCl}_{2}-\mathrm{V}$ (c, ES 4).

only ions of one element. Two cathodic peaks were observed that can be related to Ti and $\mathrm{V}$ deposition. This is also an indication that there are no heteronuclear complexes, as opposed for example to $\mathrm{Ti}-\mathrm{Al}$ alloy [2] or $\mathrm{TiB}_{2}$ [37] deposition, which are reduced in a single reaction with a fixed molar ratio.

Titanium deposition is always accompanied by vanadium deposition because of its more negative potential. The evaluation of the electrodeposition experiments, however, indicates that also during vanadium deposition simultaneously titanium deposits, because vanadium coatings always contained titanium. Even those deposits with the highest vanadium contents of almost 90 at\% (V-10 at\% Ti) contained titanium in spite of a potential difference of $E_{\mathrm{p}}\left(\mathrm{V}^{2+} / \mathrm{V}\right)-E_{\mathrm{p}}$ $\left(\mathrm{Ti}^{2+} / \mathrm{Ti}\right) \approx 100 \mathrm{mV}$. This finding could be explained by the fact that, although the ions in the melt and the electrode reactions are independent as long as there is a clean tungsten electrode, as soon as there is a vanadium deposit on the electrode titanium alloys with vanadium, which was already observed during anodic dissolution experiments at vanadium electrodes [29].

Interestingly, the anodic scan exhibits a dissolution peak of the Ti-V alloy at significantly more positive potential than that of vanadium dissolution. This indicates that the $\mathrm{Ti}-\mathrm{V}$ deposits behave nobler than pure vanadium, and within the investigated concentration range they become nobler with increasing vanadium contents (Fig. 4). During slow $\mathrm{CV}$ scans two or even more dissolution peaks were observed (Fig. 3b) that might be due to the dissolution of Ti-V alloys with different chemical compositions, while at faster scan rates the oxidation peaks merge to a single peak.

SEM investigations exhibited that composition and morphology of the deposits are closely related (Table 2). While pure or slightly alloyed coatings had a coarse crystalline structure ([28, 26] and Fig. 6c, d), vanadium-rich alloys were dendritic in shape (Fig. 7a). Titanium alloys with $\mathrm{V}$ contents between 10 and 60 at\% were dense and had a cauliflowerlike appearance. In spite of the spherical growth failures 
causing this appearance, the surface of the alloys with small vanadium contents, e.g., Ti-11V, had a very smooth surface.

Literature with the existing phase diagrams of the Ti-V system $[38,39]$ indicates the need for further experimental work. While a previously proposed miscibility gap [40] was not confirmed, the boundary of the composition range of the $\alpha+\beta$ region is not fully clear. Hagi et al. [41] detected up to ca. 19 at $\% \mathrm{~V}$ both $\alpha$ and $\beta$ phase by XRD, while at higher $\mathrm{V}$ contents only $\beta$ phase was found.

According to calculations performed in the current work with the ThermoCalc software for the thermodynamic equilibrium at $700 \mathrm{~K}$, the $\alpha+\beta$ stability range extents up to more than 60 at $\% \mathrm{~V}$ and Ti-60V consists of ca. $99 \mathrm{~mol} \% \beta$ phase and ca. $1 \mathrm{~mol} \% \alpha$ phase. In contrast, Ti- $11 \mathrm{~V}$ consists of 84 mol $\% \alpha$ phase and 16 mol $\% \beta$ phase. Consequently, both alloys are within the $\alpha+\beta$ field and $\alpha$-Ti contains ca. 1.5 at $\%$ $\mathrm{V}$, which corresponds to the solubility limit of monophasic $\alpha-\mathrm{Ti}(\mathrm{V})$, while the $\beta$ phase contains 61 at $\% \mathrm{~V}$. The equilibrium calculation is qualitatively consistent with the phases found in the electrodeposited material with the exception that small amounts of $\omega$ phase are detected by SAED instead of $\alpha$-Ti for Ti- $60 \mathrm{~V}$. The schematic $\beta$-isomorphous phase diagram [42] indicates the presence of various metastable phases, such as hexagonal and orthorhombic martensite. According to Murray [38] metastable $\omega$ occurs as intermediate product from metastable $\beta-(\mathrm{Ti}, \mathrm{V})$ within a medium composition range. Annealing at $400{ }^{\circ} \mathrm{C}$ (i.e., slightly below the electrolyte temperature in the present study) caused the beginning of $\alpha-\operatorname{Ti}(\mathrm{V})$ precipitation from $\beta / \omega$ after $20 \mathrm{~h}$ [38].

The biphasic nature of the $\alpha+\beta$ alloy Ti-11V is accompanied with element partitioning, which may take place during electrodeposition itself or may be a result of an intrinsic heat treatment at the process temperature $700 \mathrm{~K}$. We neither expect equilibrium concentrations (as calculated by ThermoCalc) nor the values determined by TEM/EDS showing $\alpha-\mathrm{Ti}$ and $\beta-(\mathrm{V}, \mathrm{Ti})$ regions to quantitatively reflect the exact phase concentration. Due to the very fine structure, it is very difficult to measure single crystals of one phase because the thickness of the TEM lamella exceeded the size of the fine grains.

The smooth surface and the small grain size of the deposits both are indications that the element partitioning may play a crucial role during the electrodeposition process at ad-atom level and is responsible for the grain refining effect. Clusters of $\alpha$ or $\beta$ phase may form on the electrode's surface and disturb crystal growth. The local enrichment of vanadium in the $\beta$ phase causes a local depletion of $\mathrm{V}$ in the adjacent regions, which is a thermodynamic condition for the formation of $\alpha$ phase. This interpretation is consistent with the finding that the monophasic deposits with low $\mathrm{V}$ contents from a $(\mathrm{LiCl}-\mathrm{KCl})_{\text {(eut.) }}-\mathrm{VCl}_{3}-\mathrm{TiCl}_{2}-\mathrm{Ti}$ (ES 7) show coarse-faceted crystal growth.

During electrodeposition, the solid phase crystallizes directly from the cathodic reduction of dissolved ions (i.e., not by solidification from liquid metal) and depending on the coating rate there is a short time for element partitioning accompanying a phase separation. This can be compared to fast cooling processes leading to metastable phases. So the presence of $\omega$ instead of $\alpha$ in the Ti-60V alloy suggests that metastable $\omega$ forms either directly during electrodeposition or from metastable (supersaturated) $\beta$ by subsequent phase transformation at the process temperature of $700 \mathrm{~K}$. The SAED investigation (Fig. 8) indicates that the amount of $\omega$ is rather low, though even a rough estimation of the phase fraction is not possible. However, it appears reasonable that the biphasic nature is also in this case responsible for grain refinement, as suggested for the $\alpha+\beta$ alloy Ti-11V.

\section{Conclusions}

Ti-V alloys with a wide concentration range can be deposited from the $(\mathrm{LiCl}-\mathrm{KCl})_{(\text {eut. }}-\mathrm{VCl}_{x}-\mathrm{TiCl}_{y}$ electrolyte system if divalent vanadium ions are generated and stabilized by metallic vanadium. The results of this study are important for the development of an electrodeposition process for titanium alloys containing vanadium (in particular Ti-6Al-4V), because for the first time correlations between the concentrations of titanium and vanadium ions, the electrodeposition potential and the compositions were established.

Depending on the composition of the deposited alloy, different constituent phases were found: the alloy with Ti-60V consisted predominantly of $\beta-(\mathrm{V}, \mathrm{Ti})$ with small amounts of
Table 2 Summary of surface morphologies of electrodeposited $\mathrm{Ti}-\mathrm{V}$ alloy and their conditions

\begin{tabular}{llll}
\hline System & Condition & Composition range & Morphology \\
\hline ES 3 & $E_{\mathrm{D}}-E_{\mathrm{P}}\left(\mathrm{V}^{2+} / \mathrm{V}\right)>0 \mathrm{mV}$ & Pure $\mathrm{V}$ & Large faceted crystals \\
ES 4-ES 6 & $E_{\mathrm{D}}-E_{\mathrm{P}}\left(\mathrm{V}^{2+} / \mathrm{V}\right)>0 \mathrm{mV}$ & $\mathrm{V}$ rich $(\mathrm{ca} .90$ at $\%)$ & Large dendrites \\
ES 4-ES 6 & $E_{\mathrm{D}}-E_{\mathrm{P}}\left(\mathrm{V}^{2+} / \mathrm{V}\right)<<0 \mathrm{mV}$ & $\mathrm{Ti} 40-90$ at\% & Cauliflower-like \\
ES 7 & $E_{\mathrm{D}}-E_{\mathrm{P}}\left(\mathrm{Ti}^{2+} / \mathrm{Ti}\right)>0 \mathrm{mV}$ & $\mathrm{Ti} \approx 90$ at $\%$ & Cauliflower-like \\
ES 7 & $E_{\mathrm{D}}-E_{\mathrm{P}}\left(\mathrm{Ti}^{2+} / \mathrm{Ti}\right)>0 \mathrm{mV}$ & $\mathrm{Ti}>99$ at\% & Large faceted crystals \\
\hline
\end{tabular}


metastable $\omega$, whereas Ti-11V consisted of $\alpha$-Ti and minor amounts of $\beta$ phase.

The biphasic structure of both alloys may be responsible for the fine microstructures and smooth surfaces of the deposits. We hypothesize that element partitioning during crystallization of two phases enforces the continuous formation of new nuclei. This behaviour is in clear contrast to pure metals and monophasic alloys deposited under the same conditions.

Acknowledgements Open Access funding provided by Projekt DEAL. We thank the German Research Foundation (DFG) for financially supporting the project (GU 1413/1-2, FR 1713/23-1).

Open Access This article is licensed under a Creative Commons Attribution 4.0 International License, which permits use, sharing, adaptation, distribution and reproduction in any medium or format, as long as you give appropriate credit to the original author(s) and the source, provide a link to the Creative Commons licence, and indicate if changes were made. The images or other third party material in this article are included in the article's Creative Commons licence, unless indicated otherwise in a credit line to the material. If material is not included in the article's Creative Commons licence and your intended use is not permitted by statutory regulation or exceeds the permitted use, you will need to obtain permission directly from the copyright holder. To view a copy of this licence, visit http://creativecommons.org/licenses/by/4.0/.

\section{References}

1. Taxil P, Chamelot P, Massot L, Hamel C (2003) Electrodeposition of alloys or compounds in molten salts and applications. J Min Met 39(1-2):177-200

2. Stafford G, Moffat T (1995) Electrochemistry of titanium in molten $2 \mathrm{AlCl}_{3}-\mathrm{NaCl}$. J Electrochem Soc 142(10):3288-3296

3. Li W, Chen Z, Wei C, Kong W, Xu B, Jia X, Diao C, Li S (2016) The electrochemical formation of Al-Cu alloys in a $\mathrm{LiCl}-\mathrm{KCl}-$ $\mathrm{AlCl}_{3}$ molten salt. Electrochim Acta 196:162-168. https://doi. org/10.1016/j.electacta.2016.02.179

4. Liu K, Liu Y-L, Yuan L-Y, Zhao X-L, Chai Z-F, Shi W-Q (2013) Electroextraction of gadolinium from $\mathrm{Gd}_{2} \mathrm{O}_{3}$ in $\mathrm{LiCl}-\mathrm{KCl}-$ $\mathrm{AlCl} 3$ molten salts. Electrochim Acta 109:732-740. https://doi. org/10.1016/j.electacta.2013.07.084

5. Liu Y-L, Yan Y-D, Han W, Zhang M-L, Yuan L-Y, Liu K, Ye G-A, He H, Chai Z-F, Shi W-Q (2013) Extraction of thorium from LiCl$\mathrm{KCl}$ molten salts by forming Al-Th alloys: a new pyrochemical method for the reprocessing of thorium-based spent fuels. RSC Adv 3(45):23539-23547. https://doi.org/10.1039/c3ra43292k

6. Sato K, Matsushima H, Ueda M (2016) Electrodeposition of Al-Ta alloys in $\mathrm{NaCl}-\mathrm{KCl}-\mathrm{AlCl}_{3}$ molten salt containing TaCl5. Appl Surf Sci 388(B):794-798. https://doi.org/10.1016/j.apsusc.2016.03.001

7. Stafford GR, Hussey CL (2001) Electrodeposition of transition metal-aluminum alloys from chloroaluminate molten salts. In: Alkire RC, Kolb DM (eds) Advances in electrochemical science and engineering, vol 7. Wiley-VCH Verlag $\mathrm{GmbH}$, Weinheim, pp 275-347

8. Janowski GM, Stafford GR (1992) The microstructure of electrodeposited titanium-aluminum alloys. Metall Mater Trans A 23A:2715-2723

9. Stafford GR (1994) The electrodeposition of $\mathrm{Al}_{3} \mathrm{Ti}$ from chloroaluminate electrolytes. J Electrochem Soc 141(4):945-953
10. Stafford GR, Tsuda T, Hussey CL (2003) Order/disorder in electrodeposited aluminum-titanium alloys. J Min Metall 39(1-2):23-42

11. Tsuda T, Hussey CL, Stafford GR, Bonevich JE (2003) Electrochemistry of titanium and the electrodeposition of Al-Ti Alloys in the lewis acidic aluminum chloride-1-Ethyl-3-methylimidazolium chloride melt. J Electrochem Soc 150(4):C234-C243

12. Song J, Mukherjee A (2016) Influence of F- on the electrochemical properties of titanium ions and $\mathrm{Al}-\mathrm{Ti}$ alloy electrodeposition in molten $\mathrm{AlCl}_{3}-\mathrm{NaCl}$. RSC Adv 6(85):82049-82056. https://doi. org/10.1039/c6ra18417k

13. Polyakova LP, Taxil P, Polyakov EG (2003) Electrochemical behaviour and codeposition of titanium and niobium in chloridefluoride melts. J Alloys Compd 359(1-2):244-255

14. Polyakova LP The study of zirconium and niobium joint electrodeposition in $\mathrm{KCl}-\mathrm{KF}-\mathrm{K}_{2} \mathrm{ZrF}_{6}-\mathrm{K}_{2} \mathrm{NbF}_{7}$. In: Wendt $\mathrm{H}$ (ed) Molten salt chemistry and technology, Dresden, Germany, 1997. Trans Tech Publications LTD, pp 351-354

15. Wu T, Ma X, Jin X (2016) Preparation of vanadium powder and vanadium-titanium alloys by the electroreduction of $\mathrm{V}_{2} \mathrm{O}_{3}$ and $\mathrm{TiO}_{2}$ powders. J Mater Res 31(3):405-417

16. Lantelme F, Kuroda K, Barhoun A (1998) Electrochemical and thermodynamic properties of titanium chloride solutions in various alkali chloride mixtures. Electrochim Acta 44(2-3):421-431

17. Lantelme F, Salmi A (1995) Electrochemistry of titanium in $\mathrm{NaCl}-$ $\mathrm{KCl}$ mixtures and influence of dissolved fluoride ions. J Electrochem Soc 142(10):3451-3456

18. Martinez AM, Castrillejo Y, Barrado E, Haarberg GM, Picard G (1998) A chemical and electrochemical study of titanium ions in the molten equimolar $\mathrm{CaCl}_{2}+\mathrm{NaCl}$ mixture at $550{ }^{\circ} \mathrm{C}$. J Electroanal Chem 449(1-2):67-80

19. Haarberg GM, Rolland W, Sterten A., Thonstad J (1993) Electrodeposition of titanium from chloride melts. J Appl Electrochem 23(3):217-224

20. Wei D, Okido M, Oki T (1994) Characteristics of titanium deposits by electrolysis in molten chloride-fluoride mixture. J Appl Electrochem 24(9):923-929

21. Baker DH, Ramsdell JD (1960) Electrolytic vanadium and its properties. J Electrochem Soc 107(12):985-989

22. Tripathy PK, Sehra JC, Bose DK, Singh RP (1996) Electrodeposition of vanadium from a molten salt bath. J Appl Electrochem V26(8):887-890

23. Lei KPV, Sullivan TA (1971) Electrorefining of vanadium prepared by carbothermic reduction of $\mathrm{V}_{2} \mathrm{O}_{5}$. Metall Trans 2:2312-2134

24. Kazakova OS, Kuznetsov SA (2012) Electrochemical behavior and electrorefining of vanadium in melts containing titanium salts. ECS Trans 50(11):181-190

25. Polovov IB, Tray ME, Chernyshov MV, Volkovich VA, Vasin BD, Rebrin OI (2014) Electrode processes in vanadium-containing chloride melts. Molten Salt Chemistry and Technology, Wiley

26. Gussone J, Vijay CRY, Haubrich J, Milicevic K, Friedrich B (2018) Effect of vanadium ion valence state on the deposition behaviour in molten salt electrolysis. J Appl Electrochem 48(4):427-434. https://doi.org/10.1007/s10800-018-1165-7

27. Peters M, Leyens C (2002) Titan und Titanlegierungen, 3rd edn. Wiley VCH, Weinheim

28. Gussone J, Hausmann J (2011) Deposition of titanium on SiC fibres from chloride melts. J Appl Electrochem 41(6):657-662. https://doi.org/10.1007/s10800-011-0284-1

29. Milicevic K, Friedrich B, Gussone J, Haubrich J (2017) Anodic dissolution of vanadium in molten $\mathrm{LiCl}-\mathrm{KCl}-\mathrm{TiCl}_{2}$. J Appl Electrochem 47(5):573-581. https://doi.org/10.1007/s 1080 0-017-1061-6

30. Berghoute Y, Salmi A, Lantelme F (1994) Internal reference systems for fused electrolytes. J Electroanal Chem 365(1-2):171-177 
31. Papaderakis A, Mintsouli I, Georgieva J, Sotiropoulos S (2017) Electrocatalysts prepared by galvanic replacement. Catalysts 7(3):80

32. Ferry DM, Picard GS (1990) Impedance spectroscopy of the $\mathrm{Ti}(\mathrm{IV}) / \mathrm{Ti}(\mathrm{III})$ redox couple in the molten $\mathrm{LiCl}-\mathrm{KCl}$ eutectic melt at $470{ }^{\circ} \mathrm{C}$. J Appl Electrochem 20(1):125-131

33. Hamer WJ, Malmberg MS, Rubin B (1956) Theoretical electromotive forces for cells containing a single solid or molten chloride electrolyte. J Electrochem Soc 103(1):8-16

34. Brenner A (1963) Electrodeposition of alloys, vol 1. Academic Press, New York

35. Landolt D (1994) Electrochemical and materials science aspects of alloy deposition. Electrochim Acta 39(8-9):1075-1090. https ://doi.org/10.1016/0013-4686(94)e0022-r

36. Baboian R, Hill DL, Bailey RA (1965) Electrochemical studies on titanium in molten $\mathrm{LiCl}-\mathrm{KCl}$ eutectic Can. J Chem/Rev Can Chim 43(1):197-205

37. Volkov SV (2002) Coordination compounds in melts. In: GauneEscard M (ed) Molten salts: from fundamentals to applications, vol 52. Kluwer Acad. Publ., Dordrecht, pp 357-373
38. Murray JL (1981) The Ti-V (Titanium-Vanadium) system. Bull Alloy Phase Diagr 2(1):48-55

39. Predel B (1998) Ti-V (Titanium-Vanadium). In: Madelung $\mathrm{O}$ (ed) Pu-Re-Zn-Zr. Springer, Berlin, pp 1-4. https://doi. org/10.1007/10551312_2842

40. Murray JL (1992) Ti-V (Titanium-Vanadium). In: ASM handbook volume 3: alloy phase diagrams. ASM International

41. Hagi T, Sato Y, Yasuda M, Tanaka K (1987) Structure and phase diagram of T-V-H system at room temperature. Trans Jpn Inst Met 28(3):198-204. https://doi.org/10.2320/matertrans1960.28.198

42. Banerjee D, Williams JC (2013) Perspectives on titanium science and technology. Acta Mater 61(3):844-879. https://doi. org/10.1016/j.actamat.2012.10.043

Publisher's Note Springer Nature remains neutral with regard to jurisdictional claims in published maps and institutional affiliations.

\section{Affiliations}

\section{Joachim Gussone ${ }^{1}$. Chakradhar Reddy Yerragudi Vijay ${ }^{1} \cdot$ Philipp Watermeyer $^{3} \cdot$ Ksenija Milicevic $^{2}$. Bernd Friedrich $^{2}$. Jan Haubrich ${ }^{1}$}

Joachim Gussone

joachim.gussone@dlr.de

1 Institute of Materials Research, German Aerospace Center (DLR), Linder Höhe, 51147 Cologne, Germany

2 IME Process Metallurgy and Metal Recycling, RWTH Aachen University, Intzestr. 3, 52072 Aachen, Germany
3 Structure and Nano-/Micromechanics of Materials, Max-Planck-Institute für Eisenforschung (MPIE), Max-Planck- Straße 1, 40074 Düsseldorf, Germany 